\title{
Transport and Health Risks of Transport
}

\author{
V. Adamec, R. Ličbinský*, R. Cholava \\ Division of Transport Infrastructure and Environment, Transport Research Centre, Brno, Czech Republic \\ *Corresponding author: roman.licbinsky@cdv.cz
}

DOI: $10.2478 / \mathrm{v} 10158-011-0011-\mathrm{y}$

\begin{abstract}
The increasing amount of gases and solid pollutants emitted into the atmosphere have a considerable impact on human health and environmental ecosystems. Specifically, long exposure to high concentrations of pollutants may lead to a shortening of life by several years due to cardiovascular and respiratory diseases, and contributes to increased risk of death. Recent studies also indicate cancer occurrences related to some pollutants, namely PM, that are hazardous not only due to their physical parameters, but mainly due to their content of many dangerous organic compounds, such as hydrocarbons, polyaromatic hydrocarbons and their derivates, and inorganic compounds, such as $\mathrm{Pb}, \mathrm{Pt}, \mathrm{Cd}, \mathrm{As}, \mathrm{Cu}, \mathrm{Zn}$, and others, nitrates, ammonia ions, sulphates, etc.
\end{abstract}

KEY WORDS: transport, health, emissions, noise, inactivity, accidents.

\section{INTRODUCTION}

The most serious issue for traffic is air pollution through emissions, due to their health and environmental risks. This negative phenomenon is evident in large cities with high traffic volumes, where, especially in recent years, a considerable increase has been recorded and the increased share on health risks was connected with the exposure of people to these pollutants. Other modes of transport, apart from car transport, contribute to air pollution as well, such as railway, air, and water transport. The electrified railways need energy which is mainly produced in power plants burning fossil fuels. But the chemical emissions produced by the combustion and non-combustion processes are not the only factors seriously threatening human health. The acoustic emissions (noise), vibrations, accident rate, or inactivity are also very serious problems. The following chapter gives a brief but complex overview of the negative traffic effects in terms of possible health risks.

\section{CHEMICAL EMISSIONS}

\subsection{Emissions from combustion processes}

The composition and size of emissions depends mainly on traffic volume, quantity and composition of fuels, type and condition of engines, and the way of driving. It is estimated that the weight unit of emissions from motorised traffic in cities and large residential areas is ten times bigger compared to emissions produced by other sources (industry, heating) and even a hundred times bigger when compared to emissions in rural areas. The exhaust gases of motor vehicles contain hundreds of chemical compounds 
in various concentrations with different effects on human health. Apart from the "classic" monitored pollutants, e.g. nitrogen oxides $\left(\mathrm{NO}_{\mathrm{x}}\right)$, carbon monoxide $(\mathrm{CO})$, carbon dioxide $\left(\mathrm{CO}_{2}\right)$, and sulphur dioxide $\left(\mathrm{SO}_{2}\right)$, attention has recently been paid to persistent organic pollutants such as polyaromatic hydrocarbons (PAH), polychlorinated dibenzodioxines (PCDF), or polychrorinated dibenzofurans (PCDF). The area which is currently being carefully monitored, as a consequence of increasing concentrations in the environment, is the particulate matter (PM), mainly their smaller fractions, whose major source is road transport. The danger of these particles does not lie only in their mechanical properties, but especially in the high-risk content of organic or inorganic pollutants (Adamec, 2005). Long-term exposure to PM effects shortens life expectancy due to cardiac and lung diseases; changes in the immune system of people are not negligible either (Bencko et al., 2006).

Whereas the biological effects and health risks of gas pollutants (e.g. $\mathrm{NO}_{\mathrm{x}}, \mathrm{CO}, \mathrm{SO}_{2}$ ) are based on their seriousness (i.e. a dose - response) and a rather simple determination of the expository concentrations is well-defined, the application of this approach is not the most suitable for PM, because the same concentration of particles at two different localities does not have to represent the same risk when considering the often very different chemical composition of the pollutants which are bound to them. In addition to the concentration of total suspended particles (TSP), particles smaller than 10 micrometers $\left(\mathrm{PM}_{10}\right)$ or soot, the issue of individual sizing fractions representation, mainly $\mathrm{PM}_{2.5}, \mathrm{PM}_{1.0}$ and composition determination has become more monitored in the world. Furthermore, findings from the last few years have shown that also concentrations lower than the set limits can damage human health, particularly over long exposure. Therefore, this group is not nowadays perceived as an inert mass of particles which could clog up the lungs and cause damage to the organism, but as a heterogeneous mixture of particles with various physical and chemical properties (Mauderly, 1999, Morawska et al., 1999) which depend on the source and the mechanism of the particles creation, and predisposes their biological effects (Ball et al., 1987, Sagai, 1993, Dockery, Pope III, 1994, Schwartz, 1994, Vedal, 1997).

PM content in the atmosphere increased during 1990 - 2001 by 12\% (THE PEP, 2004). A range of studies have shown in their conclusions the definite connection between air pollution by PM and the occurrence of respiratory diseases and asthma, which could lead, according to a study by WHO (THE PEP, 2004), to the death of children under the age of 5. The most endangered group is particularly inhabitants who live in the proximity of a road with high traffic volume. The possible consequence of the increased PM concentrations in the air is the increase in the number of deaths as a consequence of chronic bronchitis which is the fifth largest cause of global mortality. Some studies even point to the possible risk of respiratory organs cancer (THE PEP, 2004). Provo University in Utah (USA) has carried out very detailed research (Dockery, Pope III, 1994) whose results are alarming. For the period of 16 years scientists monitored 500000 people living in big cities with a high concentration of fine dust. $22 \%$ of people died during the period, out of which almost half died as a consequence of cardiac arrest. The study states that the increased content of particulate matter of $10 \mu \mathrm{g} . \mathrm{m}^{-3}$ demonstrably caused the increase of cardiac diseases by $12 \%$ and by $18 \%$ of ischemic diseases which could even lead to a heart attack. According to other sources, a $40 \%$ increase of lung cancer in the long-term exposure to high concentrations of the exhaust gases of diesel engines (Dora, Phillips (eds.), 2000), has been observed as well. A detailed study on the impacts of air pollution on population health was carried out in eight largest cities in Italy where average $\mathrm{PM}_{10}$ concentrations between 1998 and 1999 higher than $45 \mu \mathrm{g} . \mathrm{m}^{-3}$ were discovered, where, by a content reduction to $40 \mu \mathrm{g} . \mathrm{m}^{-3}$ 2000 people could have been prevented from dying (Martuzzi et al., 2002). Expert sources state that 200 people die in London every year as a consequence of air pollution from traffic, the same number have to be hospitalized, further 1000 require regular medical care 
and $500000-1000000$ people require a minor medical examination. APHEIS (Air Pollution and Health: a European Information System) states that the reduction of $\mathrm{PM}_{10}$ of $5 \mu \mathrm{g} \cdot \mathrm{m}^{-3}$ level may prevent 1560 people from possible death. If the $\mathrm{PM}_{10}$ level declines to $20 \mu \mathrm{g} . \mathrm{m}^{-3}$ the presumed number of dead people could be even reduced by 11855 (THE PEP, 2004). Switzerland, France, and Austria were dealing with a joint project on the impact of air pollution on citizens in the late 1990s. The number of dead people connected to air pollution in these countries was approximately 40000 in 1996, whereas about half of them were a consequence of pollution stemming directly from traffic. Primarily, people with weakened immune systems, asthmatics, cardiac patients, and children who inhale the exhaust gases almost "directly" from the exhaust pipes, are under threat. Emission production is linked to almost 135000 asthma attacks and 300000 attacks of bronchitis among children under 15, compared to 25000 attacks of bronchitis for adults over 25. According to various sources (Filliger et al., 1999, Dora, Phillips (eds.), 2000), up to $102000-368000$ people die annually in Europe as a consequence of air pollution, out of which $36000-129000$ deaths could be perceived as a consequence of long-term exposure to traffic pollution in European cities. Approximately $35 \%$ of those dead people could be connected directly to pollution caused by particulate matter (Filliger et al., 1999). According to the latest research carried out by the European Union (EU), 310000 people die annually in the whole EU of diseases connected with air pollution; and fine dust decreases the life expectancy of each European by nine months on average. Only in Germany this means 65000 deaths a year (Watkiss et al., 2005). Air pollution is responsible for claiming approximately seven times more lives than traffic accidents on European roads, through which "only" approximately 45 thousand people die every year. PM possible entrance to the human body depending on their size is shown in Figure 1.

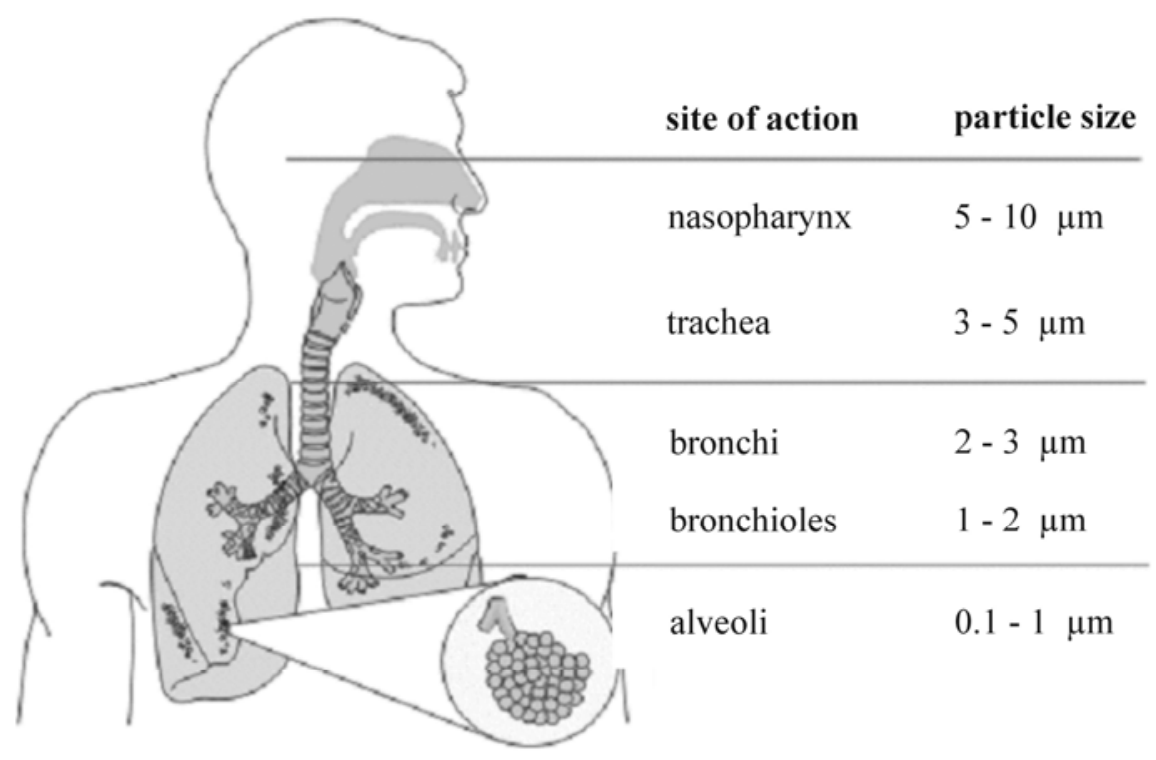

Figure 1: Distribution of particulate matter (PM) in the respiratory system (Dora, Phillips (eds.), 2000).

The recent interest in this issue and search for the solution in the Czech Republic is reflected in the fact that on the basis of the air quality evaluation more than $25 \%$ 
of the Czech population live in areas where the limits for $\mathrm{PM}_{10}$ are exceeded (Fiala, Horálek, 2003).

Not negligible amount of PM in the air also comes from regional and long-distance transport, which could influence the concentration of these particles and distort the share of traffic in the total pollution (Tiita et al., 2002). That is the reason why it is necessary to study thoroughly the physical and chemical properties of the particles which are emitted from traffic and the methods of their identification.

According to the EU directive valid in all member states, the content of fine dust in the air, particles of a diameter up to $10 \mu \mathrm{m}\left(\mathrm{PM}_{10}\right)$, may only exceed the maximum limit of $50 \mu \mathrm{g} . \mathrm{m}^{-3}$ on 35 days a year, whereas an annual average limit is determined by $40 \mu \mathrm{g} . \mathrm{m}^{-3}$ (Act No. 86/2002, Sb.). Considering the deteriorating air quality, the EU produced a study defining the contaminated regions as those where the limit figures are exceeded more often than is permitted (Watkiss et al., 2005). Among those there are some areas of the Czech Republic, such as Prague, Brno, Ústí nad Labem, Karviná, and Ostrava, where exceeding concentrations of air-borne dust occurs more than a hundred times a year. The mentioned limit values are being exceeded during the first three months of the year. A similar situation happens in some European areas as well.

The above mentioned mainly concerns the particles with a diameter up to $10 \mu \mathrm{m}$, whose contents have been monitored regularly in the Czech Republic since 2002 on the basis of the Air Protection Act (Act No. 86/2002, Sb.). Currently, the extension of monitoring and pollutant limit concentrations for finer particles with a diameter under $2.5 \mu \mathrm{m}\left(\mathrm{PM}_{2.5}\right)$ in the legislation are considered, because they go through respiratory tracks to the lungs, where they accumulate, and, therefore, they are far more dangerous than the previously observed $\mathrm{PM}_{10}$ (THE PEP, 2004).

The knowledge about harmful effects derived from a huge amount of epidemiological and toxicological studies about the overall human exposure to these particles have started these activities with the aim to reduce the concentrations of particles in the air (Schwartz, 1994, THE PEP, 2004, Krzyzanowsky et al., 2005).

Among other pollutants which negatively influence human health and originate from traffic are $\mathrm{PAH}$, which is a group of organic compounds occurring during the imperfect combustion of fossil fuels. The exhaust gasses of diesel engines contain lower concentrations of some gas emissions $\left(\mathrm{NO}_{2}, \mathrm{SO}_{2}\right)$, but, on the other hand, produce higher PM concentrations, to which a whole range of pollutants are bound, the most serious being PAH. Those are absorbed in the lungs and digestive tract and metabolized by the poly-functional oxidase system. Many of them are mutagenic and carcinogenic. A study carried out among diesel traction workers of American railways showed that workers under the age of 65, who have been exposed in the last 20 years, had a small, but nevertheless, statistically considerable, increase in the risk of lung cancer. Other studies among workers exposed to car emissions indicate that men employed as truck drivers had a statistically significant $50 \%$ increase in the risk of bladder cancer. On the basis of the results, focused on benzo(a)pyrene $(\mathrm{BaP})$ as a reference substance from the PAH group, it is estimated that the upper limit of the lifelong risk of cancer is around 62 cases per 100000 exposed people per $\mu \mathrm{g}$ of benzene of the dissolved coal emissions, dispersed in $\mathrm{m} 3$ of the surrounding air. A $0.71 \%$ content of $\mathrm{BaP}$ is expected in these emissions. The risk of cancer occurrence for people exposed to $1 \mathrm{mg} \mathrm{BaP}$ per $\mathrm{m}^{3}$ during their whole life is estimated to be 9 cases per 100000 people (Šuta, Bencko, 1998).

A very important group of substances associated with traffic emissions is nitrated polyaromatic hydrocarbons (nPAH). However, the occurrence of these substances is predominantly connected with diesel combustion in diesel engines and with chemical reactions among PAH bound to particles (fluoranthene, pyrene and benzo(a)pyrene) 
or in the air (naphthalene, phenanthrene) and $\mathrm{NO}_{\mathrm{x}}$, when both reactant groups are emitted by traffic.

The widespread introduction of unleaded fuels led to significant changes in the fuel composition in the effort to maintain sufficiently high octane rating of fuel. The octane rating of fuel is used for the expression of anti-knock properties, by comparing these properties with the reference fuel containing iso-octane. Then the percentage of iso-octane content is the octane number of fuel. In engine construction various octane numbers are used depending on the operational conditions. RON (research octane number) is important for medium speed and engine load and MON (motor octane number) for high speed and engine load. These critical values are critical for proper vehicle operation and all European fuels have to reach certain conditions for RON and MON. Olefins produced by the alkylation process in combustion having good RON, but low MON, are undoubtedly the main class of fuel substances, which leads to an occurrence of 1.3- butadiene in burnt gases. It is classified as a carcinogen, causing leukemia, and it is especially important for photochemical reactions in the atmosphere, which contribute to the occurrence of photochemical smog. The relation between olefin content in the fuel and the production of volatile organic compounds (VOC), mainly 1,3- butadiene, was demonstrated clearly in the studies (Šuta, Bencko, 1998) in which fuels with various composition were tested. The fuels with a content of arenes (aromatic hydrocarbons) fluctuating between 20 and $57 \%$ and olefins between 0.5 and $33 \%$, are typically used in the EU. The measurement results showed the dependence of benzene emissions on the original content of these hydrocarbons in fuel. An important fact is that benzene content in all fuels is approximately constant and it shows that its larger amount in the burnt gases comes from the conversions of other aromatic fuel components. The high concentrations of arenes in unleaded petrol could enhance the benzene quantity in the external environment by even $50 \%$, and considerably influence benzene concentrations even in the indoor environment of buildings.

Table 1: Overview of exposure to selected pollutants of individual modes of transport (Kingham et al., 1998).

\begin{tabular}{|l|c|c|c|c|c|}
\hline \multicolumn{1}{|c|}{ Pollutant } & Transport & $\begin{array}{c}\text { Mean } \\
\text { value }\end{array}$ & $\begin{array}{c}\text { Standard } \\
\text { deviation }\end{array}$ & Min & Max \\
\hline \multirow{4}{*}{$\begin{array}{l}\text { Benzene } \\
\left(\mu \mathrm{g} . ~^{-3}\right)\end{array}$} & Car & 108.3 & 106.2 & 15.3 & 265.5 \\
\cline { 2 - 6 } & Train & 12.9 & 10.3 & 4.2 & 30.0 \\
\cline { 2 - 6 } & Bus & 21.2 & 18.2 & 5.9 & 53.9 \\
\cline { 2 - 6 } & Bicycle - road & 26.5 & 25.9 & 5.5 & 74.6 \\
\cline { 2 - 6 } & Bicycle - field path & 15.7 & 17.5 & 4.8 & 50.7 \\
\hline \multirow{3}{*}{\begin{tabular}{l} 
Absorbed PM $\left(\mu \mathrm{g} . \mathrm{m}^{-3}\right)$ \\
\cline { 2 - 6 }
\end{tabular}} & Car & 7.6 & 4.4 & 3.5 & 14.7 \\
\cline { 2 - 6 } & Train & 5.7 & 2.0 & 3.5 & 7.7 \\
\cline { 2 - 6 } & Bus & 5.3 & 3.0 & 2.3 & 10.7 \\
\cline { 2 - 6 } & Bicycle - road & 6.3 & 4.6 & 2.9 & 15.1 \\
\cline { 2 - 6 } & Bicycle - field path & 2.7 & 2.0 & 1.2 & 6.7 \\
\hline
\end{tabular}

Other VOCs (ethylbenzene, toluene, o-, m-, p-xylene) have been discovered in emissions, in relation to initial arene content in the fuel. Approximately four times more toluene was emitted when using unleaded petrol in comparison with leaded fuel with low arene content. 
The results of these studies support the opinion that the cars using petrol with olefin and arene concentration increase the occurrence of benzene, 1,3- butadiene and other VOCs in the air and thereby they increase the risk of potential diseases, such as leukemia (Šuta, Bencko, 1998).

Table 2 provides a brief overview of selected pollutants produced by traffic which contaminate the air, and their occurrence and health risks.

Table 2: Sources and characteristics of air pollutants from traffic (Adamec et al., 2005).

\begin{tabular}{|c|c|}
\hline Pollutant & Health risks \\
\hline $\begin{array}{l}\text { Carbon dioxide } \\
\left(\mathrm{CO}_{2}\right)\end{array}$ & $\begin{array}{l}\text { It is irrespirable. A human withstands } 1.5 \% \text { concentration in the air during a period } \\
\text { of several hours without any consequences. Higher concentrations are more dangerous: } \\
\text { for example concentration of } 3-5 \% \text { is life threatening after half an hour, } 8-10 \% \\
\text { causes a rapid loss of consciousness and death. }\end{array}$ \\
\hline $\begin{array}{l}\text { Carbon } \\
\text { monoxide (CO) }\end{array}$ & $\begin{array}{l}\text { It stops the oxidation of blood in the lungs (creation of carboxyhaemoglobine), heart, } \\
\text { brain disorders, visual and hearing problems, digestion problems, and abdominal pains. } \\
\text { In the case of serious poisoning unconsciousness occurs. Death by suffocation is caused } \\
\text { by concentrations over } 750 \mathrm{mg} \cdot \mathrm{m}^{-3} \text {. }\end{array}$ \\
\hline $\begin{array}{l}\text { Sulphur dioxide } \\
\left(\mathrm{SO}_{2}\right)\end{array}$ & $\begin{array}{l}\text { Toxic gas with irritation effects, causing breath problems, changes of lung capacity } \\
\text { and lung functions. }\end{array}$ \\
\hline $\begin{array}{l}\text { Nitrogen oxides } \\
\left(\mathrm{NO}_{\mathrm{x}}\right)\end{array}$ & $\begin{array}{l}\text { Irritation effects, mild to serious bronchitis or pneumonia, even acute pulmonary } \\
\text { oedema. }\end{array}$ \\
\hline $\begin{array}{l}\text { Nitrous oxide } \\
\left(\mathbf{N}_{2} \mathbf{O}\right)\end{array}$ & $\begin{array}{l}\text { No real breath phase-out and heart problems; although possible unconsciousness } \\
\text { and consequent suffocation. Long term exposure can cause vitamin } \mathrm{B}_{12} \text { deficiency } \\
\text { nerve damage and blood cells production disorder, decrease of psychomotoric } \\
\text { function, cognitive function, memory failures. }\end{array}$ \\
\hline $\begin{array}{l}\text { Ozone } \\
\left(\mathrm{O}_{3}\right)\end{array}$ & $\begin{array}{l}\text { Exposition to } \mathrm{O}_{3} \text { causes cellular and structural changes, whereas the general influence } \\
\text { lies in lowered lung capability to execute normal functions. }\end{array}$ \\
\hline $\begin{array}{l}\text { Lead } \\
(\mathbf{P b})^{*}\end{array}$ & $\begin{array}{l}\text { Toxic metal, poisoning (chronic) shows loss of appetite, slackness, headaches } \\
\text { and artrodynia, stomach and intestine problems, cramps in abdomen, damage of liver } \\
\text { and periphery, or central nerves. }\end{array}$ \\
\hline $\begin{array}{l}\text { Cadmium } \\
\text { (Cd) }\end{array}$ & Toxic metal. \\
\hline $\begin{array}{l}\text { Nickel } \\
\text { (Ni) }\end{array}$ & Toxic metal. \\
\hline $\begin{array}{l}\text { Chrome } \\
\text { (Cr) }\end{array}$ & Toxic metal, mainly as hexahydric compounds. \\
\hline $\begin{array}{l}\text { Platinum metals } \\
\text { (Pt, Rh, Pd) }\end{array}$ & Toxic metals. \\
\hline $\begin{array}{l}\text { Polycyclic } \\
\text { aromatic } \\
\text { hydrocarbons } \\
\text { (PAH) }\end{array}$ & $\begin{array}{l}\text { Many compounds from this group have demonstrable mutagenic and carcinogenic } \\
\text { effects (benzopyrene, nitro PAH). }\end{array}$ \\
\hline $\begin{array}{l}\text { Methyl-terc.- } \\
\text { butyl ether } \\
\text { (MTBE) }\end{array}$ & $\begin{array}{l}\text { MTBE is of low acute inhaling toxicity, middle acute toxicity in its usage, it is not } \\
\text { genotoxic, but in high concentrations it can induce the occurrence of tumours in rodents' } \\
\text { bodies. Information about long-term, reproductive, and carcinogenic effects on human is } \\
\text { currently not available. }\end{array}$ \\
\hline $\begin{array}{l}\text { Volatile organic } \\
\text { compounds } \\
\text { (VOC) }\end{array}$ & $\begin{array}{l}\text { The risk connected with exposure to VOC could be divided into four main categories: } \\
\text { acute irritating effects, carcinogenicity, neuro-behavioural influences, hepatotoxic } \\
\text { and nephrotoxic affection. VOC could, in higher concentrations, cause the acute } \\
\text { irritation of eye conjunctivas and respiratory tract, headaches, dizziness, faints, overall } \\
\text { feeling of slackness, uneasiness. These effects are reversible, they disappear if exposure } \\
\text { is terminated or radically reduced. The synergy between the individual components } \\
\text { of VOC could emphasize the impact on health of some compounds from a wide spectre } \\
\text { of VOC. }\end{array}$ \\
\hline
\end{tabular}




\begin{tabular}{|l|l|}
\hline \multicolumn{1}{|c|}{ Pollutant } & \multicolumn{1}{|c|}{ Health risks } \\
\hline Benzene & $\begin{array}{l}\text { The damage of nervous system, liver, immunity, airways, leukaemia. The human } \\
\text { carcinogen classified in the group 1 (i.e. Carcinogen compounds for human) } \\
\text { IARC is shown, classified to group A according to US EPA. It is not possible } \\
\text { for it to determine the safe limit in the air as well as for genotoxic carcinogen. }\end{array}$ \\
\hline Toluene & $\begin{array}{l}\text { Inhaling experiments on animals shown that the majority of toluene is distributed to fat } \\
\text { tissue, adrenal glands, renal and brain. Serious dysfunctions of CNS and damage } \\
\text { of chromosomes of the periphery lymphocytes have been discovered. }\end{array}$ \\
\hline Styrene & $\begin{array}{l}\text { Toxic effects of styrene on the human organism consist of disorders of CNS function } \\
\text { (headaches, slackness, tension, uneasiness, vomiting) and with exposure to high } \\
\text { concentrations (over 420 mg. m3) the acute irritation of the ocular conjunctiva } \\
\text { and mucous of upper parts of the respiratory tract, increase of chromosomal aberrations } \\
\text { in the periphery lymphocytes have been observed. }\end{array}$ \\
\hline Formaldehyde & $\begin{array}{l}\text { Breathing disorders, irritable effects of the mucous (nose, eyes), asthma, skin allergy, } \\
\text { leuaemia. }\end{array}$ \\
\hline 1,3- butadiene & $\begin{array}{l}\text { In low concentrations it could cause the irritation of eyes, nose and neck. The acute } \\
\text { effects in high concentrations could lead to damage of the central nervous system, } \\
\text { headaches, decrease of blood pressure or even unconsciousness. It is a compound } \\
\text { classified as carcinogen suspicious of leukemia developing (group 2A IARC), according } \\
\text { to US EPA as a probable human carcinogen of B2 group. }\end{array}$ \\
\hline $\begin{array}{l}\text { Phe seriousness depends on their size, form, and the properties of the pollutants } \\
\text { matter } \\
\text { which are bound to these particles (for example heavy metals, PAH). Short-term } \\
\text { exposure is characteristic by breathing problems and worsening of health conditions, } \\
\text { mainly of asthmatics, so the long-term exposure leads to respiratory and cardiovascular } \\
\text { diseases, which lead to the decrease in life expectancy as well. Some studies show } \\
\text { connection with the occurrence of carcinogen diseases (lung cancer). }\end{array}$ \\
\hline
\end{tabular}

* Although Pb (tetramethyl-lead) has not been a part of fuels since 2001, its content in the environment in connection with human activity is still apparent.

\subsection{Emissions from non-combustion processes}

Although a substantial part of pollution comes from combustion processes, the key share of emissions from traffic comes the non-combustion emissions. Whereas combustion emissions are reduced with the vehicle fleet renewal, the non-combustion emissions remain on the same level and in the foreseeable future will increase with the increasing traffic volumes. All these particles, due to their size, settle quickly on the road surface and in the vicinity of their sources. They get back into the air by re-suspension as a consequence of turbulent air circulation, initiated either by passing cars or by wind blow. The negative effects of these emissions are, similarly to combustion emissions, dependent mainly on their physical and chemical properties.

\section{ACOUSTIC EMISSIONS}

\subsection{Noise emissions}

An integral part of the human environment is the noise environment. Noise is generally understood as a sound or sounds which are undesirable, disturbing, or harmful to people. An excessive occurrence is, like air pollution, one of the most serious factors which negatively influence the population's health condition and triggers a range of undesirable reactions in the human organism. The same standard affects individual types of people differently, according to given circumstances. However, it is proven that each noise, after a certain period, triggers disorders of the higher nervous system which not only leads to hearing damage, but to damage of other body organs as well, and reduce the organism's 
endurance to external negative effects and supports the development of other diseases. The modern period, mainly with the development of traffic and industry, has brought a huge amount of new sources, among which we may identify objects produced by humans (mainly means of transport, such as cars, trams, underground, airplanes), partially the humans themselves (e.g. in the classroom), as well as the natural sources (storms). The sources in the human environment and their classification are shown in the following Figure.

Road transport has become the dominant source of noise in the external environment. Rail and air transport considerably affect, through their negative effects, a smaller number of population than road transport, however, their intensity is more severe mainly at night. Among the main sources of noise there are engines at low speeds of vehicles; noise from tyres rolling on the road surface is the source of noise at higher speeds. Current research shows that approximately $60 \%$ of the amount of the overall noise burden of the population is responsible for the burden in the non-work environment, which means $70-85 \%$ of noise coming from road traffic. A lot of environmental factors, such as air temperature and humidity, its circulation, and the surface quality of objects produce noise in the environment.

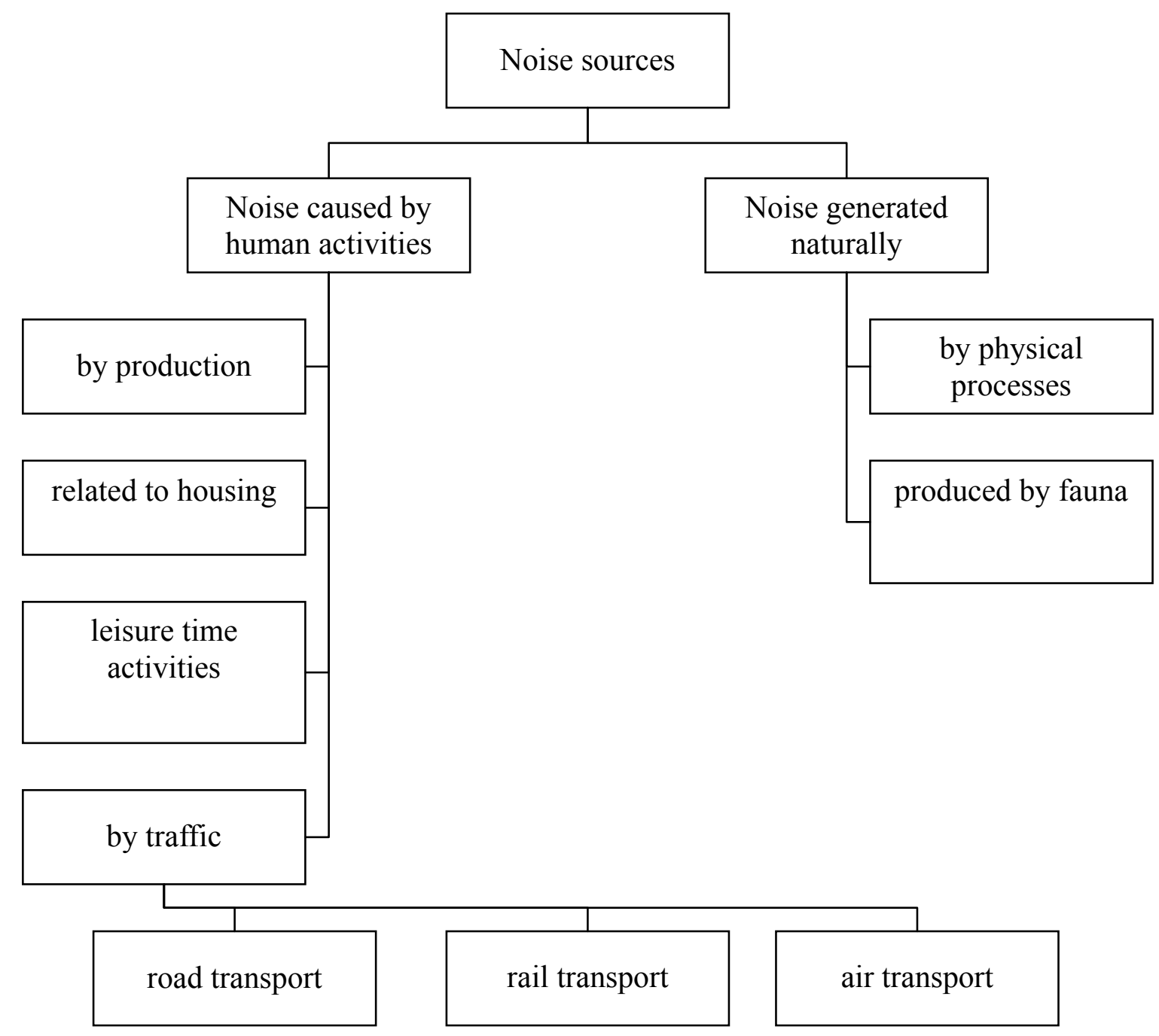

Figure 2: The sources of noise in the environment. 
Traffic noise usually does not represent a significant risk for the direct damage of hearing. More serious is the unspecific (unheard) or the so-called systemic noise The influence on the condition of human health under the impact of excessive noise will be represented by cumulating many factors even over a longer period, presumably 10 - 15 years. A long-term stay in a noisy environment causes a range of unspecific disorders which are reflected both in the mental, and, secondarily, in the physical condition. This covers mainly impaired concentration and learning ability, fatigue, sleeping disorders, aggravation of child language adoption, and adversely affects a range of physiological processes and nerve functions.

The closest relationship between prolonged exposure to noise and health conditions was demonstrated for cardiovascular diseases. Other diseases which may appear due to a prolonged exposure are diabetes, gastric ulcer and ulcerous duodenum, tumors, catarrhs of the respiratory upper tracks, gallstones and calculus in the bladder, etc. (Havránek et al., 1998).

The perception and evaluation of individual sounds made by people is different. It depends on the individual's sensitivity, functional condition of hearing, but mainly on the noise characteristics. Generally, the individual noise impulses (e.g. passing of trams) are more easier to accept for humans than long-term steady noises (noisy streets under the window); harmonic sounds are also mostly perceived as more pleasant. The human ear is able to perceive sounds of the frequency range of approximately $16 \mathrm{~Hz}$ up to $20000 \mathrm{~Hz}$. The upper limit of the frequency extent of audibility decreases with age. The sound has to have a higher intensity than the minimum sound intensity which is able to evoke the auditory perception, the so-called threshold of audibility, in order for the sound to be audible. A sound pressure level higher than $110 \mathrm{~dB}$ causes an unpleasant sound perception which is sometimes called the threshold of feeling. In the case of such sound levels, completely deaf people can also feel the tactile sensation. On even higher levels we find the threshold of pain which is accompanied by a risk of irrevocable hearing damage. The overview of subjective feelings is presented in the following Table 3.

Table 3: Sources of noise in the human environment (Vaverka et al., 1998, Berglund et al., 1999, TR, 2007).

\begin{tabular}{|l|c|l|c|}
\hline \multicolumn{1}{|c|}{ Example of noise source } & $\begin{array}{c}\text { The level of sound } \\
\mathbf{L}_{\mathbf{A}} \text { in dB }\end{array}$ & Example of noise source & $\begin{array}{c}\text { The level of sound } \\
\mathbf{L}_{\mathbf{A}} \text { in } \mathbf{d B}\end{array}$ \\
\hline Threshold of hearing & 0 & River weir & 70 \\
\hline Rustling of leaves & 10 & Passenger car $(7 \mathrm{~m})$ & 80 \\
\hline Snow-capped forest & 20 & Tram $(60 \mathrm{~km}$. h-1) & 90 \\
\hline Room in the flat at night & 30 & Symphony orchestra & 100 \\
\hline Night silence in open land & 40 & Horn of the locomotive & 110 \\
\hline $\begin{array}{l}\text { Pedestrians walking at } \\
\text { night }\end{array}$ & 50 & $\begin{array}{l}\text { Start of military jet } \\
\text { aircraft }\end{array}$ & 120 \\
\hline Common conversation & 60 & Threshold of pain & 130 \\
\hline
\end{tabular}

As has already been mentioned, the perception of noise is a subjective feeling which differs for each individual. Differentiated terms for the characterization of subjective effects on humans have been introduced. The terms are as follows:

- disturbance in which sound interferes with some activity (sleep, intellectual work, verbal communication, etc.),

- nuisance and feeling of discomfort resulting from noise exposure and noise experienced negatively by person or group concerned, 
- noise level which is a subjective evaluation of a feeling of a noise unsuitable in a specific environment,

- annoyance, which represents an unacceptable impact of the environment, or group or personal rights (Miedema, 2001, Havránek et al., 1998).

The conclusions from the assessment of the noise consequences from road transport for the life quality of the population are supported by a range of presented information on the monitoring of health and the environment within the Systemic monitoring of the population health conditions in relation to the environment. The estimates of the health risks of noise comes from the relation between the noise burden and the health indicators of the exposed population. Information on the respondents' health conditions is given in correlation with studied levels of noise recorded at corresponding localities. The current economic estimates of annual damage in the EU from environmental noise influences range from $€ 13$ to $€ 38$ billion. The elements which the estimates took into account are reductions of real estate prices, medical expenses, decreased possibility for land use, and expenses caused by disability. In spite of some uncertainties, that the estimates rate the losses in $€$ tens of billions a year (OECD, 1995).

According to the World Health Organization - WHO, around 40\% of the population in the EU is affected by noise from road traffic with an equivalent level of acoustic noise pressure which exceeds $55 \mathrm{~dB}(\mathrm{~A})$ during daytime, and $20 \%$ of the population are affected by levels exceeding $65 \mathrm{~dB}(\mathrm{~A})$. The letter A marks the used weight filter in which the course of filtration corresponds with the frequency dependence of human hearing. If we take into account all sources of noise, then approximately one half of EU citizens live in areas which are unfavourable to a quality life. It is further estimated that more than $30 \%$ of the population are exposed to an equivalent level of acoustic pressure exceeding $55 \mathrm{~dB}(\mathrm{~A})$ at night and they are disturbed during their sleep (Berglund et al., 1999).

The statistically assumed growth of selected groups of risks caused by the noise, expressed for five-decibel zones of steady exposure to night noise, is mentioned in Table 4. The prediction of an increased percentage of affected people comes from the statistical evaluation of the frequency of health problems in relation to night noise exposure $\mathrm{L}_{\text {Aeq }} 22-6 \mathrm{~h}$ for an average exposed person living in a Czech town or city. The results are mentioned in the final reports on monitoring the population's health conditions in relation to the environment, which has been in executed in the Czech Republic in a long-term. The zone $35-40 \mathrm{~dB}$ is considered to be a noise exposure in which there is no increase in the frequency of troubles and diseases. Thus the initial values actually indicate the incidence applicable in the population without the noise exposure (ZÚ Brno, 2006).

Table 4: Relative increase of problems due to exposure to traffic noise levels at night (ZÚ Brno, 2006).

\begin{tabular}{|c|c|c|c|c|c|c|}
\hline \multicolumn{7}{|c|}{ The effects of long-term exposure to external traffic noise- night $\left(\mathrm{L}_{\text {Aeq }}, 22-6 \mathrm{~h}\right)$} \\
\hline \multirow{2}{*}{ Unfavourable effect } & \multicolumn{6}{|c|}{$\mathrm{dB}(\mathrm{A})$} \\
\hline & 35-40 & $40-45$ & 45- 50 & $50-55$ & $55-60$ & $60-65$ \\
\hline $\begin{array}{l}\text { Percentage of people with } \\
\text { heart attack }\end{array}$ & Up to3.7 & $3.7-4.1$ & $4.1-4.5$ & $4.5-4.9$ & $4.9-5.4$ & $5.4-6$ \\
\hline $\begin{array}{l}\text { Percentage of people with } \\
\text { disturbed sleep }\end{array}$ & $\begin{array}{l}\text { Less than } \\
11\end{array}$ & $11-12.5$ & $12.5-13.8$ & $13.8-15$ & $15-16.5$ & $\begin{array}{l}16.5- \\
18.5\end{array}$ \\
\hline $\begin{array}{l}\text { Percentage of people using } \\
\text { tranquilizers daily }\end{array}$ & $\begin{array}{l}\text { Less than } \\
3.5\end{array}$ & $3.5-4$ & $4-4.5$ & $4.5-5$ & $5-5.7$ & $5.7-6.5$ \\
\hline
\end{tabular}


Excessive noise level in the surroundings of the roads is one of factors which are brought by the development of traffic and its seriousness is rising steadily. The hygienic imission limits of noise and vibrations at workplaces, in residential buildings, public facilities and buildings, in open spaces; and the method for their measurement and evaluation are set in the Government Regulation No. 148/2006, Sb., on health protection against the unfavourable effects of noise and vibration. The value of noise in open spaces is expressed by the equivalent level of acoustic pressure $A \mathrm{~L}_{\text {aeq,T. }}$. The highest acceptable equivalent level of acoustic pressure $A$ in open spaces (with the exception of noise from air traffic operations) is set by adding a basic noise level of $50 \mathrm{~dB}$ to the appropriate corrections for daytime or night time period and place in accordance with the appendix of this regulation.

"Amendment to the Methodology for Calculating Noise from Road Traffic" is the used computing method for the calculation of noise from road traffic in the Czech Republic. However, it is not mandatory by the legislation. The amendment also contains the methodology for noise measurement of the road traffic. This methodological document has a status of computational method for the calculations of acoustic situation conditions in the outdoor environment for the purposes of hygienic assessment. Currently, there is a second edition available of "Amendment to the Methodology for Calculating Noise from Road Traffic" from 2004. The last, and in terms of development, the highest degree of systemic models for the evaluation of the impact of traffic on acoustic situation in the outdoor environment is "Guidelines for the calculation of traffic noise levels" from 1991, which contains the calculation methods for noise calculation from road, railway, tram, and trolley-bus traffic, and from traffic in parking areas.

The graphical form of the acoustic calculations results is the acoustic map. The software form of the Czech calculation methodology is a HLUK+ software, furthermore, a whole range of foreign computing software is available, e.g. SoundPLAN, LIMA, MITHRA, CADNA, IMMI, etc., which usually provide the user with the possibility to choose from many implemented computing methods. These programmes allow the users to create a 3-D model of an area in question and perform a calculation of noise levels to find out the number of people affected by the noise.

To secure the effective system of noise evaluation and management in the environment, the Directive of the European Parliament and Council 2002/49/EC from 25 June 2002 was adopted, whose goal is to define a common approach to avoidance, prevention, and reduction of harmful noise effects on human health, and to provide public with information on the environmental noise and its effects. This Directive was implemented in the Czech legislation by Act No. 222/2006, Sb., which superseded Act No. 76/2002, Sb., on the integrated prevention and pollution limits, on an integrated pollution register, and on changes in some Acts (Act on integrated prevention), as amended, and Decree No. 523/2006, Sb., which sets the limit values of noise indicators, their calculation, basic content demands of strategic noise maps, and action plans, and conditions for public participation in their preparation (Decree on noise mapping).

According to the above-mentioned Directive No. 2002/49/ES, the noise maps (number of people, respectively residences, exposed to noise) in the surroundings of main roads, railway lines, airports, and in the agglomerations, will map the noise level affecting the population. The first stage of their production finished in 2007, in the next five years further noise maps will be processed according to the Directive and a revision will be made, eventually updating the processed maps for the surroundings of main roads, which are used by more than 6 million vehicles every year, major railway lines, which are used by 60000 trains every year, for the major airports surroundings with more than 50000 takeoffs or landings, and for agglomerations with more than 250000 inhabitants. The creation and evaluation of the strategic noise maps was immediately linked to a creation of action 
plans in 2008. Measures reducing noise, which include traffic planning, urban planning, technical measures at noise sources, selection of less noisy sources, and regulative or economic measures or incentives, have been proposed.

There are various approaches to the classification of these measures among the extensive number of measures for the reduction of the road traffic noise levels, which include measures aimed at the noise source, along the line of noise distribution, and at the receiver, and respectively on buildings. The anti-noise measures can be divided into the three following groups. Urban protective measures are among the active ones and they determine the principles for the design and reconstruction within urban planning. The main principles of these measures are related to the optimization of transport requirements and the rationalization of transport relations, and target a reduction in traffic volumes. Furthermore, they include suitable layout solutions for residential areas, the appropriate deployment of objects according to their purpose, and the architecture design of buildings. Within the set of technical measures, we could include measures aimed at the noise source (road alignment, longitudinal gradient, road pavement), measures aimed at the noise distribution, i.e. creating obstacles, which could be anti-noise walls (able to reduce noise levels by up to $15 \mathrm{~dB}$ ), embankments, material objects, and vegetation; and measures aimed at buildings, which could increase airborne sound insulation of the external windows of buildings to be protected. The third group includes organizational measures which concern the driving speed reduction, driving speed limits at night, a decrease in traffic volumes, or a change of modal split through no access for heavy vehicles, arranging detours, and the designing of one-way roads. The issue of noise levels should be dealt with from the early stages of the urban and technical solutions, where more opportunities for useful and effective solutions are available and the results are relatively cheap. The issue of anti-noise walls is more thoroughly elaborated in Chapter 7.

\subsection{Vibrations}

Vibrations represent another phenomenon which negatively influences human health. In terms of physics, under the term "vibrations" the movement of an elastic body or an environment is understood, whose individual points are oscillating around their equilibrium position. The term "trembling" is used for vibrations perceived by living organism. Noise and trembling are closely connected with each other and mutually dependent. The main source of vibrations is road and railway transport in the environment. The vibrations are formed by vehicle operation on uneven road pavement and rail tracks, and they are transferred to the surrounding built-up areas through subgrade and constructions of buildings, existing near the main traffic routes, into internal residential space, and onto standing or sitting people during the movement of means of transport. We may also encounter vibrations caused by shifts in the earth's crust - impact of earthquakes or winds on various structures. The vibrations depend on vehicle's construction, their axle pressure, speed and acceleration, the quality of road pavement, road structure and subgrade, and in case of rail transport, rail track contacts with the subgrade. Vibrations of buildings are also caused by flyovers of aeroplanes and by underground trains passing through water-bearing areas.

Vibration perception is influenced by a whole range of factors. It is a complex physiological and psychological sensation perceived by a whole range of receptors. These impulses transferred by the central nervous system to the brain, where they are integrated, and subjective sensations created. The perception size is determined not only by the frequency, but by speed as well. The exposure to intensive vibrations is connected with an unpleasant subjective perception of discomfort which could be assessed in terms of physiology, as well as psychology. Long-term exposure could cause lasting health damage. The local vibrations transmitted to the hands induce damage to some systems. The peripheral 
blood vessels, nerves of upper limbs and muscular-articular apparatus are affected the most. The symptoms of changes in the central nervous system are the accompanying phenomena in the vibration exposure.

\section{INACTIVITY}

One of the indirect traffic effects on health is the influence on lifestyle. Car use at the expense of walking or cycling means the limitation of natural physical activity which is extremely important for health. A study which describes the situation in European cities showed that cars are also used for short distances instead of walking or cycling. More than 50\% of journeys by car are shorter than $5 \mathrm{~km}$ which is a distance reachable by bicycle within 15 minutes and more than $30 \%$ of journeys by car are shorter than $3 \mathrm{~km}$ which is a distance reachable by walking in approximately 20 minutes. An average European person who lives in a city walks approximately $1 \mathrm{~km}$ a day, rides a bicycle approximately $0.5 \mathrm{~km}$ and drives by car approximately $27.5 \mathrm{~km}$ (THE PEP, 2004). The overuse of motorized transport is one, though not the only one, of the reasons of physical inactivity of the current European population.

The World Health Report from 2002 (WHO, 2002) states that in Europe there are approximately $17 \%$ (ranging $11-24 \%$ ) of physically inactive people. Another $41 \%$ (ranging $31-51 \%$ ) of people are dedicated to physical activity less than 2.5 hours a week, which is still considered to be insufficient activity in terms of the health benefits. The physical inactivity causes extensive social losses. It is estimated that it causes 600000 premature deaths in Europe. Among the significantly affected countries there are mainly those of Eastern and Middle Europe. This situation is documented by results of various studies which deal with lifestyle of the Czech population. For example, HELEN study (SZÚ, 2006), implemented within the System of monitoring the health condition of the population in relation to the environment, and which monitored a sample of population from the ages of $45-54$ in selected cities, discovered that roughly one third of men and women do not devote their leisure time to any movement or a sport activity, and only $10 \%$ of women and $19 \%$ of men are dedicated to an intensive activity. The international HAPIEE study (Health, Alcohol, and Psychosocial Factors In Eastern Europe) came to similar conclusions when studying the population at the age of $45-68$ in selected Czech cities concerning the movement activity level, and, in total, one third of men and women did not have any movement activity at all (0 hours weekly) (UCL, 2005).

The lack of physical activity, as a part of lifestyle, is considered a co-affecting factor in the long list of diseases and health indicators. It increases the risk of some diseases. Among those, there are, e.g. cardiovascular diseases, diabetes mellitus of the second type, obesity, colon cancer and breast cancer, osteoporosis, and depression. Life expectancy, stress tolerance, and self-sufficiency at old age are influenced negatively as well.

The lack of movement activity is currently becoming a serious health problem. The proportion of deaths which could be assigned to physical inactivity range between 5 and 10\%, with significant inter-regional differences, roughly 600000 deaths a year, which is approximately five times more deaths than those caused by traffic accidents (WHO, 2002).

The experts' opinions on what sufficient physical activity is vary and are developed on the basis of studies which were carried out. Currently, at least 3.5 hours of medium physical activity weekly is considered to be a minimum physical activity in terms of health benefits. According to this criterion, 41\% (31-51\%) of adults are insufficiently active. Approximately $17 \%$ of people in Europe are completely physically inactive. The studies carried out in 2002 in the EU showed that 2/3 of the European population do not reach 
the recommended level of physical activity (Sjostrom et al., 2006). Similar results were found in the HELEN study (Health, Life Style and Environment), carried out among the population of ages $45-54$, inhabitants of 25 selected cities in the Czech Republic. The insufficient physical activity (less than 30 minutes/ day) was found in the case of $62 \%$ respondents (SZÚ, 2006).

One of the consequences of insufficient movement is the increase in obesity among the population. The prevalence of obesity has more than tripled since the 1980s in many European countries. It is estimated that almost 400 million adults suffer from being overweight and approximately 130 million people are obese, an average BMI (body mass index) of the adult population of European region of WHO is nearly 26.5. If the current trend continues, the number of obese adults in Europe will rise to 150 million by 2010 , and the number of children to 15 million (Branca et al., 2007). On the basis of the HELEN study results it was found that among the monitored population of ages of $45-54$ there are $17.5 \%$ of obese people (19\% men and $16 \%$ women) and $44 \%$ people were overweight (54\% men and 34\% women) (SZÚ, 2006). The reduction of physical activity, in combination with unhealthy nutrition, also leads to increasing overweight epidemics among children throughout the whole Europe. It is an alarming fact, since children's obesity is an assumption for being overweight in adulthood; this represents a higher risk of cardiovascular diseases, diabetes, etc. Being overweight through childhood could lead to hypertension, growth of LTL and a decrease of HDL cholesterol, disrupted breathing during sleep, orthopaedic problems, and psychosocial consequences (disrupted social relationships, learning problems, impact on lifestyle).

The global strategy of nutrition and physical activity and health adopted by the World Health Assembly (WHA) defines the need for a multi-sector policy supporting physical activity, among others, by a traffic policy including non-motor traffic as a part of the transport system, and provision of conditions for accessible and safe walking and cycling (Kazmarová, Rážová, 2006).

\section{PSYCHOLOGICAL ASPECTS OF TRAFFIC}

An important aspect of traffic, in terms of human health, is the participants' mental state in road traffic. The road traffic environment is special in its way and similarly to certain jobs, people without previous medical examination and without special training are not allowed to enter this environment. An applied psychological discipline is currently dealing with this issue; its subjects of study are the mental processes and behaviour of participants in traffic and transport, both those who actively assure these processes - vehicle drivers, crews of aeroplanes, ships, etc., and passengers, pedestrians, and cyclists. Traffic psychology is focused on mentally regulated human behaviour in specific traffic conditions which are given by individual human qualities, their preliminary preparation and training, transport mode, and means of transport. The research of the system "driver - vehicle - road" and its individual parts are included in this discipline. The reliability of this system is given by the correct functioning of all its parts. The sensory inputs (process of accepting information), process of information processing (decision-making and management processes) and the driver's decision-making are being thoroughly examined. The speed accuracy and driver's reliability and possibilities of task division between a vehicle and a driver are serious issues. Mental fitness to drive a motor vehicle means the harmony between the personal psychological characteristics and the requirements and demands which the safe operation of motor vehicles puts on people. Among the crucial aspects in the driver's traffic behaviour could be considered: visual-orientaion behaviour, i.e. observation of the road, surroundings, junctions, anticipation, reaction to obstacles, readiness 
to brake, concentration and attention, psychomotorics, respectively driving techniques, i.e. movements of the steering wheel, movement coordination of other control elements, driving style with the focus on driving speed, style of negotiating curves, risky or safe driving, and last, but not least, discipline while driving, including observance of rules, road signs, restrictions, etc. What should not be omitted is the psychological vehicle analysis, which mainly concerns the information flow between the vehicle and the driver, i.e. addressing the control elements in the vehicle interior. Currently, the aim s to adapt vehicle construction to people's mental capacities, mainly in terms of their straining, which is supposed to be as low as possible, in the vehicle controlling, so that they would be able to concentrate on the road traffic in maximum extent.

\section{TRAFFIC ACCIDENTS}

The traffic accident rate is a significant problem in terms of the sustainability of transport systems. Not only the direct economic damage which occurs in accidents is concerned, but also the social dimension of sustainable trasnport is affetced. There are incomplete families often remaining after a fatality of their member, the injured often have lasting consequences which worsen their social relationships. Furthermore, accidents produce economic damage in connection with congestions during accident consequences elimination, medical expenses for the injured, and the loss of income.

Table 4: Development of accident rate on roads in the Czech Republic in the period between 1993 and 2006 (Jedlička et al., 2007).

\begin{tabular}{|l|c|c|c|c|c|c|c|c|c|c|}
\hline \multirow{2}{*}{ Incident } & \multicolumn{9}{|c|}{ Year } \\
\cline { 2 - 12 } & $\mathbf{1 9 9 3}$ & $\mathbf{1 9 9 5}$ & $\mathbf{1 9 9 7}$ & $\mathbf{1 9 9 9}$ & $\mathbf{2 0 0 1}$ & $\mathbf{2 0 0 2}$ & $\mathbf{2 0 0 3}$ & $\mathbf{2 0 0 4}$ & $\mathbf{2 0 0 5}$ & $\mathbf{2 0 0 6}$ \\
\hline Accidents & 152157 & 175520 & 198431 & 225690 & 185664 & 190718 & 195851 & 196484 & 199262 & 187965 \\
\hline Dead* & 1524 & 1588 & 1597 & 1455 & 1334 & 1431 & 1447 & 1382 & 1286 & 1063 \\
\hline Injured & 32277 & 36967 & 36608 & 37834 & 33676 & 34388 & 35438 & 34254 & 32211 & 28114 \\
\hline $\begin{array}{l}\text { Dead / 1000 } \\
\text { inhabitants }\end{array}$ & 0.15 & 0.15 & 0.15 & 0.14 & 0.13 & 0.14 & 0.14 & 0.14 & 0.13 & 0.11 \\
\hline $\begin{array}{l}\text { Injured/1000 } \\
\text { inhabitants }\end{array}$ & 3.12 & 3.58 & 3.55 & 3.67 & 3.27 & 3.37 & 3.47 & 3.35 & 3.15 & 2.74 \\
\hline
\end{tabular}

* within 30 days

The most problematic transport mode seems to be road transport, mainly individual car transport. Road transport accounts for the largest proportion of dead and injured people; e.g. in 2005 it affected 33497 people in road transport, in comparison to 507 people in railway transport in the Czech Republic (MD, 2006). The people killed or injured at level crossings due to not observing the traffic rules are still included in rail transport accident statistics.

The development of the accident rate showed continuous growth until the end of the 1990s with its peak in 1999, when 225690 traffic accidents occurred in total (see Table 4). The number of deaths was, from 1993 up until 2005, ranging between 1300 and 1600 people; it decreased significantly in 2006, which is attributed to the introduction of the point system. The traffic accidents after collisions with animals are the most apparent manifestation of fragmentation of localities by traffic infrastructure. Millions of animals are killed on roads every year at collisions with vehicles. However, a large number of killed animals does 
not necessarily lead to population endangerment, but it rather indicates that the given species is very abundant and widespread. Traffic mortality in the case of common animal species, such as rodents, foxes, common birds, form only approximately 1 to $4 \%$ of the total mortality (Iuell et al., 2003). Particularly rare species of small localized populations are sensitive to traffic mortality, in which traffic is a significant cause of mortality, and additionally species which migrate frequently between localities, among which amphibians or various species of reptiles could be classified. Populations are also endangered in specially protected areas with a higher density of transport networks and high traffic volume (in the Czech Republic, e.g. České Středohoří). Other factors affecting mortality is temperature, rainfall, the season, and the day or night time. The yearly fluctuation of mortality depends on the reproduction periods, care for the young, searching for new territories by adult offspring, seasonal migration, and the time of hunting season. A higher risk of collision is on roads which lead parallel to forests or where they intersect the forest edges with grassland.

Figure 2 shows that collisions with wild animals are the second most often cause of traffic accidents in road transport, immediately after drivers' faults. The head collision usually results in death, or serious injury of the animal, but not in all cases, especially in collisions with large mammals, such as wild boar (Sus scrofa) or red deer (Cervus elaphus); the collision usually ends well for the driver and their vehicle, as shown in Table 5.

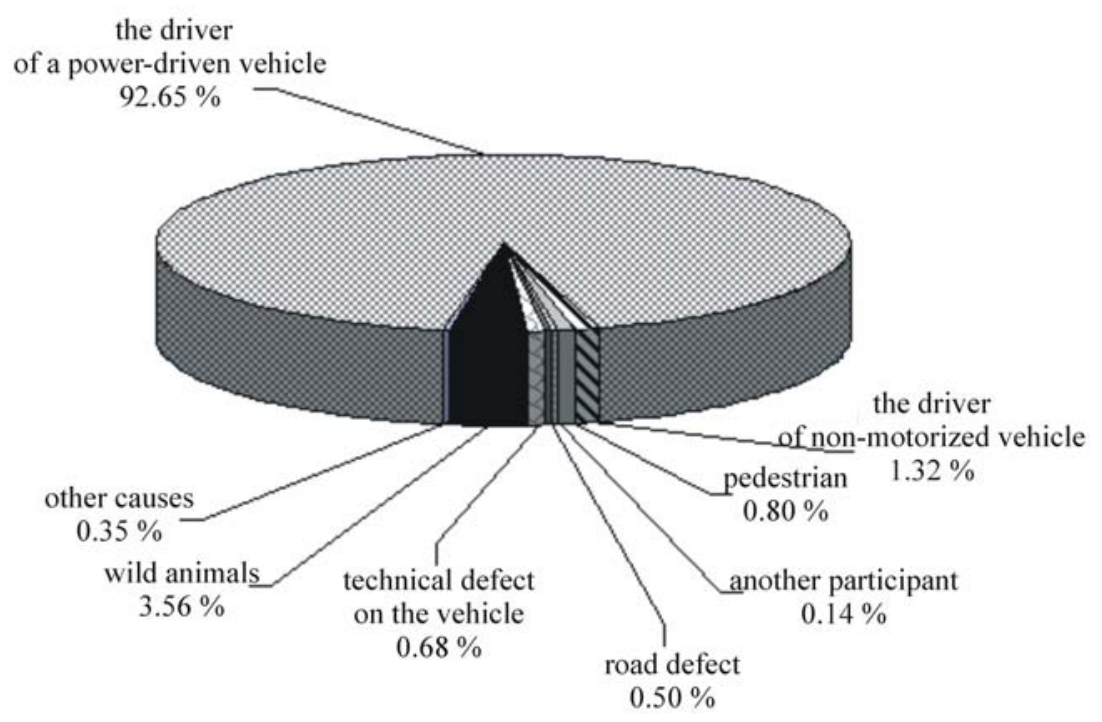

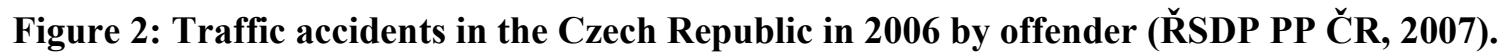

Table 5: Consequences of accidents after collisions with forest animals in the Czech Republic

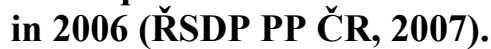

\begin{tabular}{|c|c|}
\hline Category & Consequences \\
\hline Total number of accidents with animals & 6692 \\
\hline \begin{tabular}{l|l} 
number of accidents with fatalities
\end{tabular} & 0 \\
\hline number of accidents with serious injuries & 5 \\
\hline number of accidents with slight injuries & 43 \\
\hline number of accidents with material damage & 6114 \\
\hline Number of killed people & 0 \\
\hline Number of seriously injured & 5 \\
\hline Number of slightly injured & 10 \\
\hline Material damage (in CZK millions) & 12.56 \\
\hline
\end{tabular}


Traffic safety is a very serious factor which plays an important role in the traveller's choice of means of transport. It is ironic that air transport is a very safe way of travelling, and occasional passengers are afraid of using it. It is a consequence of the media interest in plane crashes, which are highlighted in the news more often than hundreds of smaller accidents on roads. Rail transport, which is the safest means of transport in general, is sometimes shown in a similar way. The typical case is news about accidents of a train with a road vehicle at a level crossing. In spite of the fact that in absolute majority of cases it is the fault of the vehicle's driver ignoring the warning devices, the train is often shown as the offender. This contributes to the negative image of railways in the public eye.

The White Paper on European Transport Policy (European Commission, 2001) set a goal to reduce the number of fatalities on roads by $50 \%$ by 2010 in comparison to 2001 . The adoption of the National Road Safety Strategy (MD, 2005) was also confirmed by the Czech Republic. The effective measures, both in the area of improving the safety of vehicles and traffic infrastructure, and in training and education of drivers, are necessary to be taken so that this goal can be met. The introduction of the point system for traffic offense penalties in June 2006 (Act no. 361/2000, Sb.), which led to a quick decrease in the number of accidents and fatalities as well, has been a very important moment in this respect. However, it is not sure if it only reflected drivers' immediate reaction to the system of strict sanctions, which they would lose respect of very soon, or if it has really managed to apply measures with long-term benefits in practice.

\section{SUMMARY}

Transport, especially road and air transport, is an economic sector which is growing globally in most of the indicators (energy consumption, number of vehicles, transported volumes, etc.) much more quickly than corresponding GDP values. The damage to the environment and human health is increasing proportionally. The quantity of cars, in spite of various reduction measures, is rising from year to year, which is reflected in the emission growth resulting from traffic. The emissions from transport contain a whole range of dangerous chemical pollutants, all with demonstrable negative effects on human health, particularly under prolonged exposure. Similar effects, often more serious than the emission effects, come from other negative traffic features, such as noise, inactivity, and traffic accidents.

As can be seen from the above, the issue of negative influence of traffic on human health is gaining considerable importance, and is becoming one of the priorities, not only in the Czech Republic, but worldwide. A range of international events, aiming to find a solution to this issue, such as the Charter on Transport, Environment and Health, the Regional Conference of EHK/UN on Transport and the Environment etc., reflect this fact.

\section{ACKNOWLEDGEMENTS}

The study was supported by the Czech Ministry of Transport within the research project No. 04499457501 "Sustainable Transport - Chance for the Future, part 5 Transport and Environment". 


\section{REFERENCES}

Adamec, V., 2005. Vliv emisí pevných částic z dopravy na zdraví obyvatel. Doprava, vol. 47, no. 5, pp. 12-13. ISSN 0012-5520. (in Czech)

Adamec, V., Cholava, R., Vlčková, J. et al., 2005. Udržitelná doprava - šance pro budoucnost, část 5 Doprava a životni prostředí. [Prüběžná zpráva výzkumného záměru $M D \check{C} R$ č. 4499457501]. Brno: Centrum dopravního výzkumu, 52 p. (in Czech)

Bencko, V., Petanová, J., Tuček, M., 2006. Vliv dopravních emisí na imunitu člověka. Alergie, vol. 8, Supplementum 2, pp. 57 - 58. ISSN 1212-687X. (in Czech)

Ball, J.C., Young, W.C., Salmeen, L.T., 1987. Catalyst-free sodium borohydride reduction as a guide in the identification of direct-acting Ames assay mutagens in diesel-particle extracts. Mutation Research, vol. 192, no. 4, pp. 283 - 287. ISSN 0165-1161.

Berglund, B., Lindvall, T., Schwela, H.D., 1999. Guidelines for Community Noise. Geneva: World Health Organization, $161 \mathrm{p}$.

Branca, F., Nikogosian, H., Lobstein, T., 2007. The challenge of obesity in the WHO European Region and the strategies for response. Geneve: WHO, 72 p. ISBN 9789289013888.

Dora, C., Phillips, M. (eds.), 2000. Transport, environment and health (WHO Regional Publication, European series, Nr. 89). Copenhagen (Denmark): WHO, 81 p.

Dockery, D.W., Pope III, C.A., 1994. Acute respiratory effects of particulate air pollution. Annual Review of Public Health, vol. 15, pp. 107 - 132. ISSN 0163-7525.

European Commission, 2001. White paper - "European transport policy for 2010 : time to decide". Luxembourg: Office for Official Publications of the European Communities, 119 p. ISBN 92-894-0341-1.

Fiala, J., Horálek, J., 2003. Znečištění ovzduší částicemi aerosolu na dopravou ovlivněných stanicích. Ochrana ovzduši, vol. 15, no. 2, pp. 3 - 4. ISSN 1211-0337. (in Czech)

Filliger, P., Poybonnieux-Texier, V., Schneider, J. (eds.), 1999. Health costs due to roadtrafic related air pollution. Geneve (Switzerland): WHO and Federal Department of Environment, Transport, Energy and Communications, Bureau for Transport Studies, $128 \mathrm{p}$.

Havránek, J. et al., 1990. Hluk a zdraví. Praha: Avicenum, 278 p. ISBN 80-201-0020-2. (in Czech)

Iuell, B., Bekker, H., Cuperus, R. et al., 2003. Wildlife and Traffic: An European Handbook for Identifying Conflicts and Designing Solutions. Utrecht (Netherlands): EC, COST 341, KNNV Publisher, 172 p. ISBN- 90-5011-186-6.

Jedlička, J. et al., 2007. Studie o vývoji dopravy z hlediska životního prostředi v České republice za rok 2006. Brno: Centrum dopravního výzkumu, v.v.i., 138 p. (in Czech)

Kazmarová, H., Rážová, J., 2006. Doprava a zdraví - širší souvislosti. In II. konference „Doprava, zdraví a životni prostředi“. Lázně Bohdaneč, 3. - 4. 10. 2006. Brno: Centrum dopravního výzkumu. 146 p. ISBN 80-86502-33-3. (in Czech)

Kingham, S., Meaton, J., Sheard, A. et al., 1998. Assessment of exposure to traffic-related fumes during journey to work. Transportation Research Part D, vol. 3, no. 4, pp. $271-$ 274. ISSN 1361-9209. 
Krzyzanowsky, M., Kuna-Dibbert, B., Schneider, J. (eds.), 2005. Health effects of transportrelated air pollution. Copenhagen: WHO Europe, 205 p. ISBN 92-890-1373-7.

Martuzzi, M., Galasi, C., Ostro, B. et al., 2002. Health Impact Assessment of Air Pollution in the Eight Major Italian Cities. Roma: WHO, $61 \mathrm{p}$.

Mauderly, J. L., 1999. Summary of the Third colloquium on particulate air pollution and human health. In Third colloquium on particulate air pollution and human health, Durham, NC (USA), 6. - 8. 6. 1999. Irvine, CA (USA): Air pollution health effects laboratory, University of California, pp. 3-9-3-14.

MD, 2005. Národní strategie bezpečnosti silničního provozu [on-line]. Praha: Ministerstvo dopravy, 38 p. [cit. 2007-07-11]. Retrieved from: http://www.ibesip.cz/cs/Národní+strategie+BESIP/ (in Czech)

MD, 2006. Ročenka dopravy 2005. Praha: Ministerstvo dopravy ČR, 162 p. ISSN 1801-3090.

Miedema, H.M.E., 2001. Noise \& Health: How does noise affect us? In The 2001 International Congress and Exhibition on Noise Control Engineering, Den Haag, 27. 30. 8. 2001. Den Haag (Netherlands): TU Delft, 2001, pp. 3 - 20.

Morawska, L., Thomas, S., Gilbert, D. et al., 1999. A study of the horizontal and verticale profile of submicrometer particles in relation to a busy road. Atmospheric Environment, vol. 33, no. 8, pp. 1261 - 1274. ISSN 1352-2310.

OECD, 1995. Road Transport Research. Roadside Noise Abatement : OECD Report. Paris: CEDEX, 170 p. ISBN 92-64-14578-8.

ŘSDP PP ČR, 2007. Přehled o nehodovosti na pozemnich komunikacích v České republice za rok 2006. Praha: Ředitelství služby dopravní policie Policejního prezidia České republiky, 215 p. (in Czech)

Sagai, M., Saito, H., Ichonise, T. et al., 1993. Biological effects of diesel exhaust particles. In vitro production of superoxide and on vivo toxicity in mouse. Free Radical Biology \& Medicine, vol. 14, no. 1, pp. 37 - 47. ISSN 0891-5849.

Schwartz, J., 1994. Air pollution and daily mortality: a review and meta analysis. Environmental Research, vol. 64, no. 1, pp. 36 - 52. ISSN 0013-9351.

Sjostrom M. et al., 2006. Health-enhancing physical activity across European Union countries: the Eurobarometer study. Journal of Public Health, vol. 14, no. 1, pp. 1 - 10. ISSN 0090-0036.

SZÚ, 2006. Systém monitorování zdravotního stavu obyvatelstva České Republiky ve vztahu k životnimu prostredí, Hodnocení zdravotního stavu, studie HELEN (Health, Life Style and Environment), odborná zpráva za rok 2005 [on-line]. Praha: SZÚ [cit. 2007-07-10]. ISBN 80-7071-255-4. Retrieved from: http://www.szu.cz/chzp/indikatory/helen.html (in Czech)

Šuta, M., Bencko, V., 1998. Zdravotní rizika znečištění ovzduší nejvýznamnějšími automobilovými emisemi, I. Oxidy dusíku a ozon. Praktický lékař, vol. 78, no. 6, pp. 288291. ISSN 0032-6739. (in Czech)

Šuta, M., Bencko, V., 1998. Zdravotní rizika znečištění ovzduší nejvýznamnějšími automobilovými emisemi, II. Těkavé organické látky. Praktický lékař, vol. 78, no. 10, pp. 531-535. ISSN 0032-6739. (in Czech) 
Tiita, P., Raunemaa, T., Tissari, J. et al., 2002. Measurement and modelling of $\mathrm{PM}_{2.5}$ concentrations near a major road in Kuopio, Finland. Atmospheric Environment, vol. 36, no. 25 , pp. 4057 - 4068. ISSN 1352-2310.

THE PEP, 2004. Transport related Health effects with a particular focus on Children, transnational project and workshop. Vienna: THE PEP, WHO-UNECE, 64 p. ISBN 3902 338-31-8.

TR, 2007. Table of sound levels and corresponding sound pressure and sound intensity [online]. [cit. 2007-07-11]. Retrieved from:

http://www.sengpielaudio.com/TableOfSoundPressureLevels.htm

UCL, 2005. Health, Alcohol and Psychosocial factors In Eastern Europe (HAPIEE Study) [on-line]. London: UCL Department of Epidemiology and Public Health [cit. 2007-0710]. Retrieved from: http://www.ucl.ac.uk/easteurope/hapiee_open.htm

Vaverka, J., Kozel, V., Ládyš, L. et al., 1998. Stavebni fyzika 1 urbanistická, stavební a prostorová akustika. Brno: Vutium, 343 p. ISBN 80-214-1283-6. (in Czech)

Vedal, S., 1997. Ambient particles and health: lines that divide. Journal of the Air \& Waste Management Association, vol. 47, pp. 552 - 581. ISSN 1047 - 3289.

Watkiss, P., Pye, S., Holland, M., 2005. CAFE CBA: Baseline analysis 2000 to 2020, CAFE Programme, $112 \mathrm{p}$.

WHO, 2002. World Health Report 2002: Reducing risks, promoting healthy life. Geneve: WHO, 248 p. ISBN 9241562072.

Zákon č. 361/2000 Sb., o provozu na pozemních komunikacích a o změnách některých zákonů (zákon o silničním provozu), ve znění zákona č. 60/2001 Sb., zákona č. 478/2001 Sb., zákona č. 62/2002 Sb., zákona č. 311/2002 Sb., zákona č. 320/2002 Sb., zákona č. 436/2003 Sb., zákona č. 53/2004 Sb., zákona č. 229/2005 Sb., zákona č. 411/2005 Sb., zákona č. 76/2006 Sb., zákona č. 226/2006 Sb., zákona č. 264/2006 Sb. a zákona č.342/2006 Sb. (in Czech)

Zákon č. 86/2002 Sb. o ochraně ovzduší a o změně některých dalšich zákonů (zákon o ochraně ovzduší). (in Czech)

ZÚ Brno, 2006. Životni podmínky a jejich vliv na zdravi obyvatel Jihomoravského kraje [online]. Brno: Zdravotní ústav se sídlem v Brně [cit. 2007-07-11]. ISBN 80-239-8219-2. Retrieved from: http://zubrno.cz/studie/ (in Czech) 